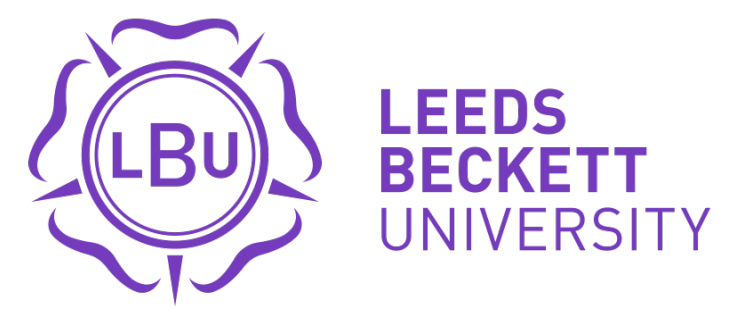

Citation:

Burrai, E and Hannam, K (2017) A reply to the responses by Sharpley, Reid and Coghlan on 'responsible volunteer tourism'. Journal of Policy Research in Tourism, Leisure and Events, 10. pp. 1-2. ISSN 1940-7963 DOI: https://doi.org/10.1080/19407963.2017.1362810

Link to Leeds Beckett Repository record:

https://eprints.leedsbeckett.ac.uk/id/eprint/4354/

Document Version:

Article (Accepted Version)

This is an Accepted Manuscript of an article published by Taylor \& Francis in Journal of Policy Research in Tourism, Leisure and Events on 24 August 2017, available online: http://www.tandfonline.com/10.1080/19407963.2017.1362810

The aim of the Leeds Beckett Repository is to provide open access to our research, as required by funder policies and permitted by publishers and copyright law.

The Leeds Beckett repository holds a wide range of publications, each of which has been checked for copyright and the relevant embargo period has been applied by the Research Services team.

We operate on a standard take-down policy. If you are the author or publisher of an output and you would like it removed from the repository, please contact us and we will investigate on a case-by-case basis.

Each thesis in the repository has been cleared where necessary by the author for third party copyright. If you would like a thesis to be removed from the repository or believe there is an issue with copyright, please contact us on openaccess@leedsbeckett.ac.uk and we will investigate on a case-by-case basis. 


\section{A reply to the responses by Sharpley, Reid and Coghlan on 'Responsible}

Volunteer Tourism'.

The aim of our paper was to develop a critique of responsibility in tourism and, more specifically, in volunteer tourism. In our discussion we highlighted the lack of political engagement of tourists and responsible tourism practitioners and the de-contextualisation of responsible volunteer tourism practices from wider geopolitical landscapes. In opening this dialogue, we contested both the practices and discourses of responsible volunteer tourism. Instead, we advocate the need of a self-reflective and critical consideration of responsible tourism theory and the reconsideration of its practices.

The contributions of Sharpley, Reid and Coghlan respectively raise the important issues of the impossibility of having responsible volunteer tourism (Sharpley, 2017), how beneficial volunteer tourism can be within sport-for-development events (Reid, 2017) and working with the system instead of just opposing the industry (Coghlan, 2017). Although we agree with the importance of remaining optimistic towards actions motivated by solidarity and good intentions, we remain cautious in positively framing the concepts of responsible and volunteer tourism within contemporary societies. In our analysis, we take a step back from tourism and consider the role of volunteering more in general. Contemporary volunteering has been developed based upon the idea that public good should reduce the intervention of the state. Thus, "an organic civil" society, rather than the state, becomes responsible for societal welfare (Smith, 2010: 830).

In acknowledging the political, economic and social contexts where voluntarism emerges, we take a different position from Sharpley (2017) who highlights a difference in terms of responsibility between volunteering overseas and volunteer tourism. According to Sharpley, the former should be considered 'responsible' whereas this is not the case for volunteering while on holiday. In our view, international volunteering is strongly framed within neoliberal ideas of responsibility, development, activism and global citizenship (Baillie Smith and Laurie, 2011). In some cases, it can exacerbate local problems and can reinforce "global geographies of inequality [...] [and] colonial and postcolonial imaginaries of development" (ibid., 2011:546).

Similarly, volunteering in sport for development while overseas calls for reflection on the concept of responsibility. This is because, sport for development can replicate the same failures of top-down economic aid carried out within the tourism field. Moreover, sport events for development highlight the separation between the 'poor' and 'underdeveloped' South and 'rich' and 'developed' North. We do not doubt that sport can make important contributions to aspects of development on a micro-level of intervention, however we remain sceptical about the benefits for the wide socio-political contexts where sport for development occurs. In contrast with the view of Coghlan (2017), we apply this argument to short term (i.e. event-based) and longer term volunteering. 
Undoubtedly, we value Coghlan's suggestion to remain optimistic about working with the volunteer tourism system but we also advocate the importance of critically understanding volunteer tourism practices within contemporary geopolitics which allows for a re-consideration of the concept of responsibility rather than an acceptance of the neoliberal status quo. Ultimately, we need to fundamentally re-imagine what volunteer tourism should be and for whom.

\section{References}

Baillie Smith M. and Laurie N. (2011) International volunteering and development: global citizenship and neoliberal professionalisation today, Transactions of the Institute of British Geographers, 36, pp.545-59.

Smith, M. J. (2010) From big government to big society: changing the statesociety balance, Parliamentary Affairs, 63 (4), pp. 818-833. 